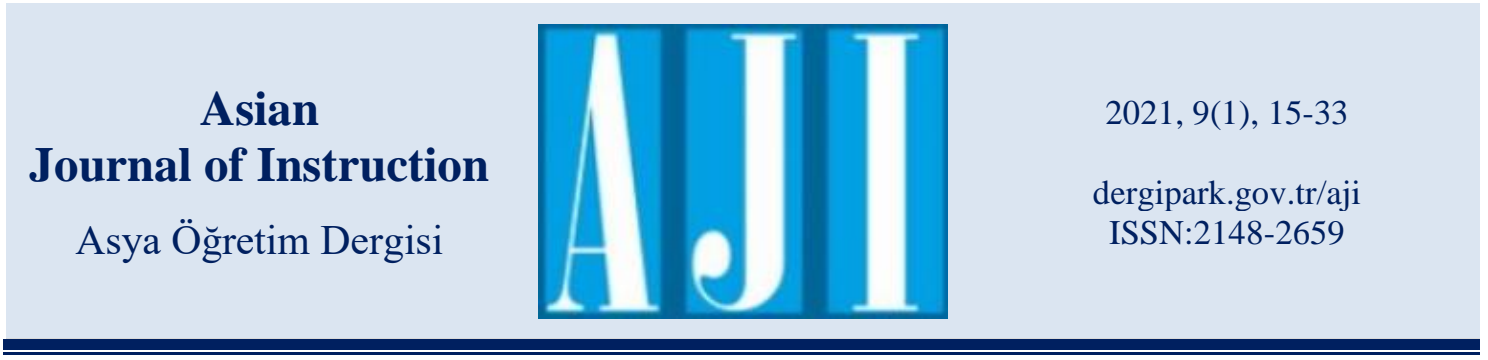

\title{
İlkokul Öğrencilerinin Yazılı Anlatım Becerileri ile Yazma Öz Yeterlik İnançlarının İncelenmesi*
}

\author{
Gökmen Gülli ${ }^{1}$, Yasemin Kuşdemir ${ }^{2}$
}

Gülli, G., \& Kuşdemir, Y. (2021). İlkokul öğrencilerinin yazılı anlatım becerileri ile yazma öz yeterlik inançlarının incelenmesi. Asya Ögretim Dergisi, 9(1), 15-33. https://doi.org/10.47215/aji.819217

$\ddot{\mathbf{O z}}$

$\mathrm{Bu}$ araştırmanın amacı, ilkokul dördüncü sınıf öğrencilerinin yazılı anlatım becerileri ile yazma öz yeterlik inanç düzeyleri arasındaki ilişkinin belirlenmesidir. İlişkisel tarama modeline göre desenlenen araştırmanın evrenini, 2594 dördüncü sınıf öğrencisi oluşturmaktadır. Araştırma, Kırıkkale il merkezinde gerçekleştirilmiştir. Basit tesadüfi örnekleme tekniğine göre, evren üzerinde \%99 güven düzeyi esas alınmış ve örneklem 563 olarak tespit edilmiştir. Araştırmaya katılan öğrencilerin yazılı anlatım puanlarını belirlemek için Yazılı Anlatım Değerlendirme Formu; yazma öz yeterlik inancını belirlemek için Yazma Öz Yeterlik Ölçeği kullanılmıştır. Veriler 2018-2019 eğitimöğretim yılında bahar döneminde toplanmıştır. Araştırmanın amacı öğretmen ve öğrencilere açıklanmış, öğrenciler ders saatleri içinde sınıf ortamında veri toplama araçlarını cevaplamışlardır. Araştırmada ulaşılan bulgular değerlendirildiğinde, öğrencilerin yazılı anlatım becerilerinin kabul edilebilir yeterlik düzeyinde olduğu anlaşılmıştır. İlkokul dördüncü sınıf öğrencilerinin yazılı anlatım puanları cinsiyet değişkenine göre değerlendirildiğinde kız öğrencilerin erkek öğrencilerden daha başarılı olduğu belirlenmiştir. Ayrıca 563 ilkokul dördüncü sınıf öğrencisinin yazma öz yeterlik inançlarının yüksek düzeyde olduğu; yazma öz yeterlik inancı ile yazılı anlatım becerisi arasında düşük ve olumlu yönlü anlamlı bir ilişki olduğu belirlenmiştir. Araştırmanın bulgularından hareketle, yazılı anlatım becerilerinin geliştirilmesi için öğrencilerin yazdığı metinlerin öğretmenler tarafından incelenmesi ve onlara hatalarıyla ilgili geri bildirim verilmesi önerilmektedir. Bunun yanında öğrenciler yazı yazma konusunda desteklenip teşvik edilmelidir.

Anahtar Kelimeler: Yazılı anlatım, yazma öz yeterliği, yazma eğitimi

\section{Analysis of Written Expression Skills and Writing Self-Efficacy Beliefs of Primary School Students}

\begin{abstract}
This study aims to determine the relationship between the written expression skills and writing self-efficacy belief levels of primary school fourth grade students. The study was designed in relational survey model and the target population consisted of 2594 primary school fourth grade students. The research was conducted in the city center of

\footnotetext{
* Bu makale birinci yazarın, ikinci yazarın danışmanlığında hazırladığı yüksek lisans tezinden üretilmiştir. Makalenin bir bölümü 2019 tarihinde Antalya'da düzenlenen Uluslararası Sınıf Öğretmenliği Sempozyumu'nda sözlü bildiri olarak sunulmuştur.

${ }^{1}$ Sinıf Öğretmeni, https://orcid.org/0000-0001-9061-7191, gokmen.glli@gmail.com

2 Doç.Dr., Kırıkkale Üniversitesi Eğitim Fakültesi, https://orcid.org/0000-0002-8687-3229, yaseminkusdemir@kku.edu.tr
} 
İlkokul Öğrencilerinin Yazılı Anlatım Becerileri ile Yazma Öz Yeterlik İnançlarının İncelenmesi

Kirıkkale. According to simple random sampling technique, $99 \%$ confidence level was taken as basis on the population and the research sample was determined as 563. In order to determine written expression scores of the students included in the study, Written Expression Assessment Form was used. In addition, Writing Self-Efficacy Scale was used to determine the levels of writing self-efficacy belief of the students. Data were collected in the spring term of 2018-2019 academic year. The aim of the study was explained to the teachers and students and subsequently, the students answered the data collection tools in the classroom environment during class hours. When the findings obtained from the study were evaluated, it was seen that the written expression skills of the students were at an acceptable level of competence. It was also found that female students were more successful than male students when the written expression scores of primary school fourth graders were evaluated according to gender variable. In addition, it was determined that 563 primary school fourth grade students in the study had a high level of writing selfefficacy beliefs and there was a low-level and positive significant relationship between writing self-efficacy belief and written expression skill. Based on the findings of the study, it is recommended that teachers examine the texts written by students in order to improve their written expression skills and to give them feedback about their mistakes. In addition, students should be supported and encouraged to write.

Keywords: Written expression, writing self-efficacy, teaching of writing

\section{Giriş}

İnsanoğlunun sosyal ve düşünce hayatında önemli değişimlere yol açan bir unsur olarak yazı, kültür, dil, duygu ve düşünce birikimini gelecek nesillere aktarabilen bir iletişim aracıdır. $\mathrm{Bu}$ yeni iletişim aracı, uygarlıkların gelişiminde önemli bir rol oynarken aynı zamanda bireylerin düşünce dünyasına da katkı sağlamıştır. Kuralları belli olan bir sistemin kullanımıyla gerçekleşen yazma işi (Keçik \& Uzun, 2004), bir anlatım biçimi; harf ve sembollerin bir araya getirilmesi sonucunda göstergelerden oluşan bir sonuçtur. Yazma, duygu ve düşünceleri anlatabilmek için uygun işaretlerin psikomotor olarak üretilmesi (Akyol, 2015); zihinde yapılandırılan bilgi, düşünce, duygu ve isteklerin belirli kurallarla aktarılması (Güneş, 2013) şeklinde farklı biçimlerde tanımlanmaktadır.

Kaligrafik bir eylem olarak adlandırılan yazma, düşünmenin metin oluşturmak için üst düzeyde kullanılabilmesi biçiminde de izah edilmektedir (Karadağ \& Kayabaş1, 2011: 990). Bilgiyi doğru kaydetme; mektuplar, yönergeler, el kitabı, raporlar, öneriler ve grafikleri bir araya getirerek yaratıcı ya da özgün dokümanlar oluşturma şeklindeki tanımda ise yazmanın iletişim ve etkileşim özelliğine dikkat çekilmektedir (Soylu \& Akkoyunlu, 2019). Aslında yazmak, ileri düzeyde bir metin üretmektir (Kellog, 2008). Düşünceleri keşfetmenin ve yeni bilgiler üretmenin bir yolu olarak dil bilgisi, heceleme, noktalama ve biçimle ilgili bilgiler gerektiren yazma becerisi, pek çok zihinsel ve duygusal işlemin birlikte kullanımını da zorunlu kılmaktadır. Bu bağlamda, yazma, el, göz ve beynin eş güdümüyle sembol ve işaretlerin kullanılarak duygu, düşünce, tecrübe, bilgi, gözlem ve hayallerin zihinde yapılandırıldığı ve anlatıldığ 1 bir dil becerisidir. Yazma, zahmetli bir zihinsel faaliyet olup dikkat ve kontrol gerektirmektedir (Sharples, 1999). Kazanılması çaba ve emek isteyen yazma (Gündüz \& Şimşek, 2011), öğrencilerin dili kullanma, bilgiyi düzenleme, düşünce üretme, bilgi birikimlerini ve zihinsel sözlüklerini oluşturma gibi zihinsel süreçler yoluyla dil becerilerini geliştirmelerine imkân sağlamaktadır (Kodan, 2016). Bu bakımdan yazma, anlaşılması güç bir süreç, geliştirilmesi gereken önemli bir dil becerisidir. Çocuğun yazma becerilerinin gelişmesi, bilgiyi transfer etmesini, düşüncelerini gözden geçirip düzenlemesini bu da daha üst düzey yazılı anlatım yapabilmesini sağlamaktadır (Akyol, 2006).

\subsection{Yazılı Anlatımın Özellikleri}

Yazılı anlatım, düşünce gücüne sahip olanların, görüş, fikir ve duygularını, gözlemlerini, tecrübelerini, konuyla ilgisi ölçüsünde planlayıp dilin kurallarına uygun biçimde ifade etmesidir (Göçer, 2010). Anlatım süreci, dil bilgisi, üretim, yazı düzeni, dil bilim ve kavrama gibi özel yazılı anlatım ögelerinin yanı sıra, noktalama, el yazısı, kelimeyi doğru yazma, yaratıcılık ve 
kendini ifade edebilme gibi birbirine bağlı beceri ve bileşenlerden oluşmaktadır (Sharpio, 1996). Her biri yazılı anlatımın mutlak ögeleridir. Kapsamı oldukça geniş olan yazılı anlatım, edebi türler, günlük notlar, raporlar, bilimsel metinler gibi birçok yazılı ürünü barındırmaktadır. Okullarda yazılı anlatımın geliştirilmesi ve yapılması, öğrencilerin kendilerini özgür ve rahat ifade edebilmelerine yardımcı olur.

\subsubsection{Yazılı Anlatımda Biçim ve Okunaklılı Özellikleri}

Yazılı anlatımın biçimle ilgili özellikleri, yazının kâğıt üzerindeki görüntüsü ve yazının kolay okunabilmesi ile ilgilidir. Temel hedefi, okunabilir ve anlamlı bir metnin yazılmasını sağlamak olan yazı öğretimine öncelikle kalem ve kâğıt gibi yazma materyallerinin doğru kullanılması ve çizgi çalışmaları ile başlanmaktadır. Uygun hızda yazı yazabilen bir öğrencinin noktalama işaretlerini doğru kullanması, kağıt üzerinde uygun kenar boşlukları bırakarak yazıya görsel bir bütünlük kazandırması beklenmektedir. Okunaklı bir yazı için harflerin yazım kurallarını doğru uygulamak, kuyruk ve uzantıları uygun şekilde yapmak, nokta, şapka gibi imleçleri ( $\breve{g}$, ö, â ) uygun yerleştirmek, satır takibine dikkat etmek gerekmektedir. Bilgisayarda yazılan metinlerde bu yeterlikler sağlanmakla birlikte kâğıt üzerinde el yazısı ile yazılan metinlerde bunların gelişmesi için özel beceri, dikkat ve farkındalığa ihtiyaç vardır. Okunaklı olmayan bir yazıda, harflerin gerekenden büyük, geniş, dar veya okunamayacak kadar küçük olmasi; harfler ve heceler arasında orantısız boşlukların bırakılması; bir cümle içinde kelimeler arasındaki boşluğun orantısız olması; harf ve kelimelerin satır çizgisi üzerine yazılamaması; harflerin kuyruk veya uzantılarının orantısız yapılması gibi sorunlar dikkat çekmektedir (Kuşdemir, 2018). Çocuklarda okunaklı el yazısı yazma becerisinin gelişimi hem bir çocuğun yaşam boyu kullanacağı bir beceri sağlaması açısından hem de bir toplumun yazma kültürü açısından büyük önem teşkil etmektedir. İlkokul birinci sınıftan itibaren çocuk, harf sembollerini öğrenmekte ve otomatikleşmeye başlamaktadır (Gök \& Baş, 2020). Yazılı anlatımda kullanımı zorunlu olan noktalama işaretleri, duygu ve düşünceleri daha açık ifade etmek, cümlenin yapısını ve duraklama noktalarını belirlemek, okumayı ve anlamayı kolaylaştırmak, sözün vurgu ve ton gibi özelliklerini belirtmek için kullanılmaktadır (TDK Sözlük, 2019). Noktalama işaretlerinin yazının anlaşılmasını kolaylaştırma; cümle ögelerinden, iç cümle, ara cümle ve yan cümleleri birbirinden ayırma; cümledeki vurgu, ezgi ve durakları belirleme işlevleri vardır. Yazıda noktalama işaretlerine ve imlâ kurallarına dikkat edilmemişse metnin konusunu doğru şekilde anlatabilmek zorlaşır ve anlam okuyucuya tam olarak geçmez (Batur, Erkek, Özen \& Ellialtı, 2017). İlkokulun ilk yıllarında, harflerin biçim ve ebatlarının gelişimini sağlamak için yazının okunaklılık boyutuna odaklanılırken ilerleyen sınıflarda yazma suretiyle oluşturulan metnin içeriği önem kazanmaktadır.

\subsubsection{Yazılı Anlatımda İçerik Özellikleri}

Okunabilir ve anlaşılabilir metin üretebilmek için yazıda okunaklılık ile birlikte yazının içeriğine odaklanmak gerekmektedir. Yazılı anlatımın içerik özellikleri, konu, plan (anlatım düzeni), başlık, cümle ve paragraf yapısı, söz varlığı, ana fikir ve yardımcı fikirler olarak sıralanabilir. İçerik özellikleri, yazma sürecinin zihinsel aşamasında tasarlanır. Yazı yazacak kişi yazmaya başlamadan önce hangi konu üzerinde yazacağına karar verir ve bununla ilgili zihninde bir plan tasarlar. Konu, yazılı anlatımın temelini oluşturur (Karadağ \& Maden, 2013). Metinde neyin anlatılacağı, hangi duygu ve düşüncelerin ifade edileceği ve bunlara yönelik anlamın alanı konuyu oluşturmaktadır (Altunkaya, 2019). Yazı, ana fikir ve yan düşüncelerden teşekkül eder. Ana fikir, okunan metinde, dinlenilen bir konuşmada veya seyredilen bir filmde verilmek istenen temel düşüncedir (Kuşdemir \& Katranc1, 2016). Yan düşünce, yazma konusunun içinde, yazma ihtiyacının oluştuğu anlam alanında yer alan ve ana düşünceyi farklı yönlerden destekler nitelikte, yazma amacını destekleyen düşüncedir (Karadağ \& Maden, 2013). Yazı eğitiminde öğrencilerin kendi duygu ve düşüncelerini daha etkili biçimde anlatması ve 
yazma becerilerinin gelişmesini sağlamak için ilgilerine uygun konular seçmek gerekmektedir. Özellikle ilkokulun ilerleyen dönemlerinde daha çok yazının içeriği üzerinde çalışılmaktadır. İçerik oluşturulurken ilk olarak metnin konusu, metnin kimler için yazılacağı (arkadaşa mektup, tüm sınıfın okuyacağı bir gazete haberi) ve yazma gayesi belirlenmelidir. Yazılacak metnin taslağı oluşturulduktan sonra paragraflardaki düşünce ve ayrıntıların anlamlı bir bütün olarak sıralanması gerekmektedir. Ana fikre ve konuya uygun bir başlık oluşturmak; doğru bilgilere yer vermek; konuyu doğru anlatabilmek için uygun kelime seçimi yapmak; atasözü, deyim ve kavramları yerinde kullanabilmek; konuyla ilgili üretilen fikirleri desteklemek için örneklere, karşılaştırma ve sebep-sonuç ilişkilerine, gözlemlere, tecrübelere değinmek; olayları oluş sırasına göre açıklamak nitelikli bir yazı içeriği oluşturabilmek için yapılması gerekenlerdendir.

\subsection{Yazma Öz Yeterliği}

Sosyal bilişsel kuramın inceleme alanlarından biri olan öz yeterlik, davranışın meydana gelmesinde etkili olan niteliktir ki bireyin belli bir performansı göstermek için gerekli etkinlikleri düzenleyip, başarılı olarak yapma kapasitesi hakkında kendisine ilişkin yargısı olarak tanımlamaktadır (Bandura, 1997). İnsanların kendi kendini düzenleme ve yansıtma yeteneğine sahip olduğu görüşüne dayanan sosyal bilişsel kuramın temel ilkesi olan öz yeterlik (Stang, 2001), yeterlik kavramını bireyin kendi benliğine indirgemesidir (Özdemir \& Erdoğan, 2017). Öz yeterlik ile bireylerin duyguları arasında güçlü bir bağ vardır. Bu bağ sayesinde bireylerin karşılaştıkları durumlara verecekleri tepkiler şekillenmektedir. Öz yeterlik inancının, bireyin motivasyonunu ve eylemlerini düzenlemesinde belirleyici ve önemli bir işlevi olduğu belirtilmektedir (Bandura, 1989).

Öz yeterlik inancına yönelik açıklamalardan yazma öz yeterliğinin, bireyin kendi yazma yeterliğinin farkında olması gibi bir çıkarım yapılabilir. Bireyin nasıl yazdığı ve yazı yazma işini tamamladıktan sonra karşılaşacağı sonuç hakkındaki beklentilerini ifade eden yazma öz yeterliği (Kuşdemir \& Gülcegül, 2018), öğrencilerin yazılı anlatımla ilgili olan duygu ve düşüncelerini etkilemektedir. Doğrudan yazma yeteneğini etkilememekle birlikte yazmaya yönelik inancı güçlü olan öğrenciler yazmada daha başarılıdır (Pajares \& Valiante, 1997). Bu öğrencilerin yazma sürecinde kolay ilerledikleri, yazma öz yeterlik inancı düşük olan öğrencilerin ise yazmaya karşı ilgisiz olduklanı ve yazmaktan daha kolay vazgeçebildikleri bilinmektedir (Pajares, 2007). Öz yeterlik inancının, yazma davranışını, yazma stratejilerinin kullanımını ve yazma yeterliklerini en iyi yordayan değişken olduğu da belirtilmektedir (Soylu \& Akkoyunlu, 2019). Bir insanın kendi yazma becerisi ile ilgili yüksek yazma öz yeterlik inancına sahip olması demek, etkili yazma becerisine ve bilgisine sahip olduğuna inanması anlamına gelmektedir. Araştırmalar yazma süreçleri ve yetkinlik hakkındaki inançların yazma başarısı için etkili olduğunu göstermektedir (Mascle, 2013). Öz yeterlik inancı yüksek olan öğrencilerin, yazma öz yeterliği düşük olanlara kıyasla zor bir yazma görevi ile karşılaştıklarında gösterdikleri çaba daha fazladır (Stang, 2001). Bu sebeple öğretmenlere yazmaya ilişkin öz yeterlik inancının bu becerinin geliştirilmesindeki rolünün bilincinde olarak öğrencilerinin yazma yetkinliklerini iyi değerlendirmeleri tavsiye edilmektedir (Pajares \& Valiante, 1997).

\subsection{Araştırmanın Amacı}

Araştırmanın amacı, "ilkokul dördüncü sınıf öğrencilerinin yazma öz yeterlik inançları ile yazılı anlatım becerileri arasındaki ilişkinin" incelenmesidir. Bu amaca uygun olarak aşağıdaki sorulara cevap aranmıştır:

1. İlkokul dördüncü sınıf öğrencilerinin yazılı anlatım becerileri ne düzeydedir?

2. İlkokul dördüncü sınıf öğrencilerinin yazılı anlatım becerileri; 
2.1. cinsiyete göre anlamlı farkl11ık göstermekte midir?

2.2. sinıf mevcuduna göre anlamlı farkl1lık göstermekte midir?

3. İlkokul dördüncü sınıf öğrencilerinin yazma öz yeterlik inançları ne düzeydedir?

4. İlkokul dördüncü sınıf öğrencilerinin yazma öz yeterlik inançları;

4.1. cinsiyete göre anlamlı farkl1lık göstermekte midir?

4.2. sınıf mevcuduna göre anlamlı farklılık göstermekte midir?

5. İlkokul dördüncü sınıf öğrencilerinin yazılı anlatım becerileri ile yazma öz yeterlik inançları arasında anlamlı bir ilişki var mıdır?

\section{Yöntem}

\subsection{Araştırma Modeli}

Araştırmada ilişkisel tarama modeli kullanılmıştır. Tarama araştırmaları, olayların, nesnelerin, varlıkların, kurumların, grupların ve çeşitli alanların "ne" olduğunu belirlemeye çalışmaktadır (Kaptan, 1998). Bireylerin tutumlarını, eylemlerini, fikir ve inançlarını belirleme ihtiyacı duyulduğunda tarama araştırmaları değişkenler arasındaki ilişkileri tetkik ve tahmin etmeye, alt gruplardaki değişimi anlamaya yardımcı olabilirler (Christen, Johnson \& Turner, 2015). Bu araştırmada ilişkisel tarama modelinin kullanılmasının temel sebebi, araştırmanın değişkenlerinden olan yazma öz yeterlik inancı ve yazılı anlatım becerisi arasındaki ilişkiyi belirleyebilmektir.

\subsection{Evren ve Örneklem}

Araştırmanın evrenini 2018-2019 eğitim öğretim yılının ikinci döneminde Kırıkkale il merkezindeki 35 resmi ilkokulda öğrenim gören 2594 dördüncü sınıf öğrencisi oluşturmaktadır. Araştırmanın örnekleme yöntemi basit tesadüfi yöntemdir. Evren üzerinde \%99 güven düzeyi için gerekli büyüklük tesadüfi örnekler için örneklem büyüklügüu, güven düzeyleri ve güven aralıkları dikkate alınarak (Cohen, 2007) 563 öğrenci olarak belirlenmiştir. Örneklem grubuna dahil olan ögrencilerle ilgili özellikler Tablo 1'de sıralanmıştır:

Tablo 1. Araştırmaya Katılan Öğrencilerin Demografik Özellikleri

\begin{tabular}{lccccccc}
\multirow{2}{*}{ Cinsiyet } & K1z & Erkek & \multirow{2}{*}{ Sinıf Mevcudu } & $10-15$ kişi & $16-20$ kişi & $21-25$ kişi & $26-30$ kişi \\
\cline { 2 - 5 } \cline { 5 - 7 } & 318 & 245 & & 146 & 100 & 166 \\
\hline
\end{tabular}

Tablo 1'e göre araştırma örnekleminde kız öğrencilerin sayısının erkeklere göre daha fazla olduğu anlaşılmaktadır. Araştırmaya katılan öğrencilerin üçte ikisinin bulundukları sınıfların mevcudunun 26' dan az olduğu belirlenmiştir.

\subsection{Veri Toplama Araçları}

Araştırmanın verilerini toplamak amacıyla dört farklı veri toplama aracı kullanılmıştır. $\mathrm{Bu}$ araçların adları aşağıda sıralanmıştır:

1. Kişisel Bilgi Formu

2. Yazılı Anlatım İçin Yönerge Listesi

3. Yazılı Anlatım Değerlendirme Formu

4. Yazma Öz Yeterlik Ölçeği

\subsubsection{Kişisel Bilgi Formu}


İlkokul Öğrencilerinin Yazılı Anlatım Becerileri ile Yazma Öz Yeterlik İnançlarının İncelenmesi

Araştırmaya katılan öğrencilerin demografik özellikleri hakkında bilgi toplamak için araştırmacılar tarafından hazırlanan "Kişisel Bilgi Formu" kullanılmıştır. Bu formda öğrencilerin cinsiyeti ve bulunduğu sinıf mevcudunu belirlemeye yönelik çoktan seçmeli maddeler yer almaktadır.

\subsubsection{Yazılı Anlatım İçin Yönerge Listesi}

Örneklem grubundaki öğrencilerin yazılı anlatım yapabilmeleri için onları yazı yazmaya yönlendirecek bir yönergeler listesi oluşturulmuştur. Yönergenin hazırlanma aşamaları aşağıda sıralanmıştır:

1. Yönerge ifadelerinin bulunduğu havuzun oluşturulması

2. İfadelerin bir sınıf ve bir Türkçe öğretmeni tarafından incelenmesi

3. İfadelerin dil ve anlatım açısından düzenlenmesi

4. Yönerge ifadeleri ile ilgili alan uzmanlarından görüş alınması

Tüm bu aşamalar sonunda oluşturulan "Yazılı Anlatım İçin Yönerge Listesi" ndeki yönergeler aşağıda siralanmıştır:

1. Yönerge: Karakterler: Samet (İlkokul dördüncü sınıf öğrencisi), Cevdet Bey (Baba), Ayşe Hanım (Anne), Mehmet Ali Bey (Öğretmen), Samet'in sınıf arkadaşları. Verilen karakterleri dikkate alarak konusu "Samet'in Karne Günü" olan bir yazı yazınız.

2. Yönerge: En sevdiğiniz çizgi film hangisidir? Bu filmi anlatan bir yazı yazınız.

3. Yönerge: Listede verilen soruları dikkate alarak en sevdiğiniz arkadaşınızla yaşadığınız bir anıyı yazınız. (“En sevdiğiniz arkadaşınız kim?", "Olayın geçtiği yer neresidir?”, "Olay ne zaman ve nasil oldu?", "Neler hissettiniz?").

4. Yönerge: Bugünlerde sizi çok mutlu eden bir olay oldu mu? Bu olayı yazınız.

\subsubsection{Yazıll Anlatım Değerlendirme Formu}

Öğrencilerin yazılı anlatım düzeylerinin belirlenmesi için kullanılan "Yazılı Anlatım Değerlendirme Formu"ndaki madde ve ölçütlerin belirlenme süreci üç aşamadan oluşmaktadır:

1. Alan Yazın Taranması: Değerlendirme formunda ele alınacak ana özelliklerin ve bunlara ait diğer ayrıntıların belirlenmesi için İlkokul Türkçe Öğretim Programı'ndaki yazma kazanımları irdelenmiştir. Konu ile ilgili araştırma raporları, tezler ve diğer kaynaklar okunmuştur. Bu kapsamda ilkokul öğrencilerinin yazdıkları yazılarda bulunması gereken asgari özelliklerle bu yaş grubunun yazılarında programa ve yaş düzeyine göre göstermesi gereken yeterlikler sıralanmıştır. Yazılı anlatım özelliklerini içeren bir madde havuzu oluşturulmuştur.

2. Uzman Görüşü Alınması: Madde havuzu, elektronik mektup ile Türkçe eğitimi ve sınıf öğretmenliği alanında doktora derecesine sahip 15 uzmana gönderilmiştir. Mektupta, araştırmanın amacı izah edilerek maddelerin araştırma konusu ve örneklem grubunun özelliklerine uygunluğu ile ilgili görüş belirtmeleri istenmiştir. Mektuba cevap veren 11 uzmanın görüşleri dikkate alınarak maddeler yeniden düzenlenmiştir. Uzmanların görüşlerine göre değerlendirme formunda bulunmasına karar verilen maddelerin öğrenci seviyesine uygunluğunu anlayabilmek için ayrıca ilkokul dördüncü sınıfa eğitim veren ve mesleki kıdemi 10 yıl olan üç sınıf öğretmeni de formu incelemiş ve düzenlenmesine destek olmuşlardır. 
3. Formun Değerlendirme Ölçütlerinin Belirlenmesi: "Yazılı Anlatım Değerlendirme Formu" 30 maddeden oluşmaktadır. Yazma ile ilgili bir yeterliği belirten her maddenin karşısında "Yeterli" (3); "Kabul Edilebilir" (2); "Yetersiz" (1) olarak ifadeler yerleştirilmiştir. Maddelerin yazının farklı özellikleri ile ilgili dağılım göstermesi sonucunda ortak özellik gösteren maddeler bir araya getirilerek iki ana bölüm oluşturulmuştur:

1. Bölüm: Yazıda biçim, dil ve anlatım özelliklerini kapsayan bölümdür.

2. Bölüm: Yazıda içerik özelliklerini kapsayan bölümdür.

Araştırmaya katılan ilkokul öğrencilerinin yazılı anlatım düzeyleri, alt bölümlerden alınan puanlarla ve bu bölümlerden alınan puanların toplanması ile oluşan toplam puan üzerinden değerlendirilmiştir. Bir öğrencinin yazısı 3 tür puan almıştır: (1) biçim, dil ve anlatım özelliklerinden alınan puan (45 puan); (2) içerik özelliklerinden alınan puan (45 puan); (3) Yazılı anlatım toplam puanı (90 puan). Değerlendirilen bir yazının ilgili maddeleri sağlayıp sağlamadığı bu ölçütlere göre puanlanmıştır.

\subsubsection{Yazma Öz Yeterlik Ölçeği}

Araştırmaya katılan öğrencilerin yazma öz yeterlik inançlarını belirlemek amacıyla Güneş, Kuşdemir ve Bulut (2017) tarafından geliştirilen "Yazma Öz Yeterlik Ölçeği” kullanılmıştır. 10 maddeden oluşan ölçek üçlü likert tipindedir ve Cronbach Alpha değeri ,69'dur. Güvenirlik değerinin iyi düzeyde olması sebebiyle veri toplama aracı olarak bu ölçeğin kullanılması uygun görülmüştür (Uzunsakal ve Yıldız, 2018). Ölçekteki maddeler, "Bana Uygun (3)", "Bana Biraz Uygun (2)" ve "Bana Hiç Uygun Değil (1)" şeklinde puanlanmıştır. Ölçekteki maddelerden iki cümle örnek olarak aşağıda sunulmuştur:

1. "Yeni öğrendiğim kelimeleri yazdığım metinlerde kullanabilirim."

2. "Yazı yazmak benim için zor bir etkinliktir."

\subsection{Veri Toplama Süreci}

Araştırmanın verileri 2018-2019 eğitim-öğretim yılında ikinci döneminde araştırmacılar tarafından toplanmıştır. Bu süreç üç adımda gerçekleştirilmiştir:

1. Araştırma izninin alınması: Kırıkkale İl Millî Eğitim Müdürlüğü’nden izin alınması; okul yönetcileri ve sınıf öğretmenleri ile bilgilendirme görüşmelerinin yapılması.

2. Veri toplama araçlarının uygulanmasından önceki işlemler: 2019 yılında Nisan ayında veri toplama aracının uygulama takviminin belirlenmesi için okul yönetimleri ve öğretmenlerle görüşme yapılması.

3. Veri toplama araçları ile uygulama aşaması: $\mathrm{Bu}$ aşama iki farklı oturumda gerçekleştirilmiştir. 1. Oturum: Kişisel bilgi formu'nun doldurulması ve yazma öz yeterlik ölçeğinin cevaplanması. 2. Oturum: Öğrencilerin yazılı anlatım konusunu belirleme yönelik yönerge listesine göre yazılı anlatım yapması.

Araştırmaya katılan öğrencilerin sınıf öğretmenleri ile uygulama takvimi oluşturulmuş, belirlenen gün ve saatlerde okullar ziyaret edilerek veri toplama araçları uygulanmıştır. Veri toplama süreci her bir sınıfta farklı günlerde olmak üzere iki oturumda gerçekleştirilmiştir. İlk oturum yaklaşık olarak 30 dakika; ikinci oturum 40-60 dakika sürmüştür. İkinci oturumda öğrenciler Yazılı Anlatım Konusunu Belirleme Yönelik Yönerge Listesinden kendi seçtikleri yönerge ve konuya uygun bir metin yazmışlardır. Uygulama tamamlandıktan sonra veriler incelenip tasnif edilmiş ardından analiz işlemleri yapılıışıır. 


\subsection{Verilerin Analizi}

Araştırmanın verileri bilgisayar ortamında sayısal olarak kaydedilmiştir. Analiz sürecinde bilgisayar destekli istatistik paket programı kullanılmıştır. İstatistik paket programına kaydedilen verilerin çözümlenmesinde kullanılacak analiz tekniklerine karar verebilmek için normallik analizi yapılmıştır. Çarpıklık ve basıklık değerlerinin $+1,5$ ve $-1,5$ değerleri arasında olduğu durumlarda dağılımın normal dağılım olarak gerçekleştiği (Tabachnick ve Fidell, 2013) kabul edilmektedir. Analiz sonuçlarına göre yazma öz yeterlik (Skewness: -,722 ve Kurtosis: ,045), yazılı anlatım (Skewness: -,004 ve Kurtosis: -,315), yazılı anlatımın alt boyutu olan biçimsel/dil ve anlatım özellikleri (Skewness: ,194 ve Kurtosis: -,480) ve içerik özellikleri alt boyutunda (Skewness: -,004 ve Kurtosis: -,237) veriler normal dağılım göstermektedir. Verilerin analiz sürecinde yapılan çalışmalar şunlardır:

1. Öğrencilerin yazılı anlatım becerilerinin ve alt boyutlarının düzeylerini belirleyebilmek için aritmetik ortalama $(\overline{\mathrm{X}})$ ve standart sapma $(\mathrm{S})$ değerleri hesaplanmıştır.

2. Araştırmaya katılan öğrencilerin öz yeterlik inançlarının ve yazılı anlatım beceri düzeylerinin cinsiyet değişkenine göre farklılık gösterip göstermediğini belirlemek için aritmetik ortalama $(\overline{\mathrm{X}})$ ve standart sapma $(\mathrm{S})$ değerleri hesaplanmış ve bağımsız örneklem t-Testi yapılmıştır.

3. Araştırmaya katılan öğrencilerin genel yazılı anlatım becerilerinin ve yazma öz yeterlik düzeylerinin sınıf mevcuduna göre farklılık gösterip göstermediğini belirleyebilmek amacıyla aritmetik ortalama $(\bar{X})$, standart sapma $(\mathrm{S})$ değerleri hesaplanmış ve varyans analizi (ANOVA) yapılmıştır.

4. Araştırmaya katılan öğrencilerin yazılarının biçim, dil ve anlatım özelliklerinden aldıkları puanların sınıf mevcuduna göre gösterdiği farklılığı saptamak için yapılan Scheffe testi yapılmıştır.

5. Araştırmaya katılan öğrencilerin yazılı anlatım beceri düzeylerinin sınıf mevcuduna göre gösterdiği farklılığın hangi gruplar arasında olduğunu belirlemek için Games-Howell testi yapılmıştır.

6. Öğrencilerin yazma öz yeterlilik düzeyi ile yazılı anlatım becerileri arasındaki ilişkiyi belirlemek için doğrusal ilişki (korelasyon) analizi yapılmıştır. Katsayı 0.30'dan küçük ise ilişkinin zayıf; 0.30-0.70 arasında ise orta; 0.70 'den büyük ise ilişkinin yüksek düzeyde olduğu belirtilmektedir (Köklü, Büyüköztürk ve Çokluk, 2007).

\subsection{Etik Kurul İzin}

Bu makale, "İlkokul Öğrencilerinin Yazılı Anlatım Becerileri ile Yazma Öz Yeterlik İnançlarının İncelenmesi” adlı yüksek lisans tezinden üretilmiştir. Araştırmanın verilerinin toplanabilmesi için öncelikle Milli Eğitim Bakanlığı'nın Araştırma, Yarışma ve Sosyal Etkinlik birimine (https://ayse.meb.gov.tr/basvurudev/\#) çevrim içi yapılan başvuru sonucu izin belgesi alınıştır. Bu izin belgesi, araştırmanın amacı ve veri toplama araçlarını içeren ekler dosyası Kırıkkale Üniversitesi Sosyal Bilimler Enstitüsü aracıllı̆ı ile Kırıkkale İl Milli Eğitim Müdürlügü̈’ne iletilmiştir. Kırıkkale İl Milli Eğitim Müdürlüğü'nün 25.04.2019 tarihli ve 79140815-44-E.8265962 sayılı izin belgesi ile araştırmanın verileri toplanmıştır. Veri toplama uygulaması 2019 yılında Mayıs ayı sonunda tamamlanmıştır. "İlkokul Öğrencilerinin Yazılı Anlatım Becerileri ile Yazma Öz Yeterlik İnançlarının İncelenmesi" adlı yüksek lisans tezi 22.07.2020 tarihinde Kırıkkale Üniversitesi Sosyal Bilimler Enstitüsü tarafından kabul edilmiştir. "İlkokul Öğrencilerinin Yazılı Anlatım Becerileri ile Yazma Öz Yeterlik İnançlarının İncelenmesi" başlıklı araştırmada etik kurallara uyulmuştur. 


\section{Bulgular}

\section{1. İlkokul Dördüncü Sınıf Öğrencilerinin Yazılı Anlatım Beceri Düzeylerine İlişkin Bulgular}

Araştırmaya katılan ilkokul dördüncü sınıf öğrencilerinin yazdıkları yazılar biçim, dil, anlatım ve içerik özellikleri açısından değerlendirilmiştir. Ayrıca bu özelliklerden elde edilen puanların genel toplamı da yazılı anlatım becerisini ifade etmesi bakımından incelenmiştir. Elde edilen bulgular Tablo 2'de sunulmuştur:

Tablo 2. Yazılı Anlatım Beceri Düzeylerinin Betimlenmesi

\begin{tabular}{lccc}
\hline Yazı Özellikleri & $\mathbf{N}$ & $\overline{\mathbf{X}}$ & $\mathbf{S}$ \\
\hline Biçimsel, dil ve anlatım özellikleri & 563 & 26,4281 & 5,71877 \\
İçerik özellikleri & 563 & 28,0373 & 6,46015 \\
Yazılı Anlatım Toplam Puan & 563 & 54,4654 & 10,88733 \\
\hline
\end{tabular}

Tablo 2'ye göre araştırmaya katılan öğrencilerin yazılı anlatım beceri düzeyi $(\bar{X}=54,46)$ yüksektir. Ancak bu düzey dikkatle incelendiğinde orta puan aralığının sınırında olduğu anlaşılmaktadır. Öğrencilerin yazdıkları metinler, biçim, dil ve anlatım özellikleri açısından $(\overline{\mathrm{X}}=26,42)$ orta düzeyde; içerik özellikleri açısından $(\overline{\mathrm{X}}=28,03)$ yüksek düzeydedir. İçerik özellikleri puanları yüksek düzey aralığında olsa da puanın alt sınırına yani orta düzeye yakın olduğu belirtilebilir. $\mathrm{Bu}$ bağlamda ilkokul dördüncü sınıf öğrencilerinin yazılı anlatım becerilerinin iyi bir gelişim göstermediği düşünülmektedir.

İlkokul dördüncü sınıf öğrencilerinin yazılı anlatım becerileri cinsiyet değişkeni açısından incelenmiştir. $\mathrm{Bu}$ amaçla bağımsız örneklemler $\mathrm{t}$ testinden elde edilen ulaşılan bulgular Tablo 3'te sunulmuştur:

Tablo 3. Yazılı Anlatım Düzeylerinin Cinsiyet Değişkenine Betimlenmesi

\begin{tabular}{|c|c|c|c|c|c|c|c|}
\hline Yazının Özellikleri & Cinsiyet & $\mathbf{N}$ & $\overline{\mathbf{X}}$ & $\mathbf{S}$ & Sd & $\mathbf{t}$ & p \\
\hline \multirow{2}{*}{$\begin{array}{l}\text { Biçim, Dil ve } \\
\text { Anlatım Özellikleri }\end{array}$} & $\mathrm{K} 1 \mathrm{z}$ & 318 & 28,32 & 5,49 & \multirow{2}{*}{561} & \multirow{2}{*}{9,70} & \multirow{2}{*}{, $000 *$} \\
\hline & Erkek & 245 & 23,97 & 5,04 & & & \\
\hline \multirow{2}{*}{ İçerik Özellikleri } & $\mathrm{K} 1 \mathrm{z}$ & 318 & 30,14 & 6,07 & \multirow{2}{*}{561} & \multirow{2}{*}{9,46} & \multirow{2}{*}{, $000^{*}$} \\
\hline & Erkek & 245 & 25,31 & 5,92 & & & \\
\hline \multirow{2}{*}{$\begin{array}{l}\text { Yazılı Anlatım } \\
\text { Toplam Puanı }\end{array}$} & Kız & 318 & 58,47 & 10,10 & \multirow{2}{*}{561} & \multirow{2}{*}{10,92} & \multirow{2}{*}{, $000^{*}$} \\
\hline & Erkek & 245 & 49,28 & 9,62 & & & \\
\hline
\end{tabular}

${ }^{*} \mathrm{p}<, 05$

Tablo 3'teki bulgulara göre yazılı anlatım toplam puanları $\left(\mathrm{t}_{(561)}=10,92,<, 05\right)$, yazılan metinlerin biçim, dil ve anlatım özellikleri $\left(\mathrm{t}_{(561)}=9,70,<, 05\right)$ ile içerik özellikleri $\left.(\mathrm{t}=561), 9,46,<, 05\right) \mathrm{k}$ ız öğrencilerin lehine anlamlı farklılık göstermektedir. Kız öğrencilerin yazdıkları metinlerin biçim, dil, anlatım ve içerik özellikleri bakımından erkek öğrencilerin yazdıkları metinlere göre daha iyi düzeyde olduğu belirtilebilir.

İlkokul dördüncü sınıf öğrencilerinin yazdıkları yazılar sınıf mevcudu değişkenine göre incelenmiştir. Elde edilen bulgular Tablo 4'te sunulmuştur: 
İlkokul Öğrencilerinin Yazılı Anlatım Becerileri ile Yazma Öz Yeterlik İnançlarının İncelenmesi

Tablo 4. İçerik Özelliklerinin Sınıf Mevcuduna Göre Betimlenmesi

\begin{tabular}{|c|c|c|c|c|c|c|c|c|c|c|}
\hline \multicolumn{5}{|c|}{ Betimsel Analiz Sonuçları } & \multicolumn{6}{|c|}{ ANOVA Sonuçları } \\
\hline $\begin{array}{l}\text { Sinıf } \\
\text { Mevcudu }\end{array}$ & $\mathbf{N}$ & $X$ & $\mathrm{~S}$ & $\begin{array}{c}\text { Varyansın } \\
\text { Kaynağ } 1\end{array}$ & $\begin{array}{l}\text { Kareler } \\
\text { Toplamı }\end{array}$ & $\mathrm{Sd}$ & $\begin{array}{c}\text { Kareler } \\
\text { Ortalaması }\end{array}$ & $\mathrm{F}$ & $\mathrm{p}$ & Fark \\
\hline $10-15$ kişi & 151 & 27,13 & 27,139 & G. Aras1 & 319,356 & 3 & 106,452 & & & \\
\hline 16-20 kişi & 146 & 27,80 & 27,808 & G. İçi & 23134,861 & 559 & 41,386 & & & \\
\hline $21-25$ kişi & 100 & 29,39 & 29,390 & Toplam & 23454,217 & 562 & & 2,572 & 053 & - \\
\hline 26-30 kişi & 166 & 28,24 & 28,241 & & & & & & & \\
\hline Toplam & 563 & 28,03 & 28,037 & & & & & & & \\
\hline
\end{tabular}

Tablo 4'teki bulgulara göre öğrencilerin yazdığı metinlerin içerik özellikleri ile sınıf mevcudu değişkeni arasında anlamlı bir farklılık $\left(\mathrm{F}_{(3,562)}=2,572 ; \mathrm{p}>, 05\right)$ olmadığı anlaşılmaktadır. $\mathrm{Bu}$ bulgu, sınıfın kalabalık olmasının veya sınıftaki öğrenci sayısının öğrencinin yazdığı bir metinde konu, ana fikir, kurgu vb. diğer özelliklere yer vermesi ile ilgili olmadığı fikrini düşündürmektedir. İlkokul dördüncü sınıf öğrencilerinin yazdıkları metinlerin biçim, dil ve anlatım özellikleri sınıf mevcudu değişkenine göre de incelenmiş, bulgular Tablo 5'te sunulmuştur:

Tablo 5. Biçim, Dil ve Anlatım Özelliklerinin Sınıf Mevcudu Değişkenine Göre Betimlenmesi

\begin{tabular}{|c|c|c|c|c|c|c|c|c|c|c|}
\hline \multicolumn{5}{|c|}{ Betimsel Analiz Sonuçları } & \multicolumn{6}{|c|}{ ANOVA Sonuçları } \\
\hline Sinıf Mevcudu & $\mathrm{N}$ & $X$ & $\mathrm{~S}$ & $\begin{array}{c}\text { Varyansın } \\
\text { Kaynağ } 1 \\
\end{array}$ & $\begin{array}{l}\text { Kareler } \\
\text { Toplamı }\end{array}$ & $\mathrm{Sd}$ & $\begin{array}{c}\text { Kareler } \\
\text { Ortalaması } \\
\end{array}$ & $\mathrm{F}$ & $\mathrm{p}$ & Fark \\
\hline 10-15 kişi & 151 & 25,80 & 5,889 & G. Aras1 & 326,845 & 3 & 108,948 & & & \\
\hline 16-20 kişi & 146 & 25,77 & 5,677 & G. İçi & 18052,991 & 559 & 32,295 & & & \\
\hline $21-25$ kişi & 100 & 27,79 & 5,489 & Toplam & 18379,837 & 562 & & 3,374 &, $018^{*}$ & $\begin{array}{l}1-3 \\
2-3\end{array}$ \\
\hline 26-30 kişi & 166 & 26,76 & 5,611 & & & & & & & \\
\hline Toplam & 563 & 26,42 & 5,719 & & & & & & & \\
\hline
\end{tabular}

Tablo 5'e göre öğrencilerin yazılarının biçim, dil ve anlatım özelliklerinden aldıkları puanlar sinıf mevcuduna göre anlamlı farklılık göstermektedir $\left(\mathrm{F}_{(3,562)}=3,374 ; \mathrm{p}<, 05\right) . \mathrm{Bu}$ farkl11ığ saptamak için yapılan Scheffe testine göre, 21-25 öğrenci mevcutlu sınıfların öğrencileriyle 1015 ve 16-20 öğrenci mevcutlu sınıfların öğrencileri arasında 21-25 kişilik sınıflarda okuyan öğrenciler lehine anlamlı farklılık olduğu anlaşılmıştır.

Araştırmaya katılan ilkokul öğrencilerinin yazdıkları yazıların toplam yazılı anlatım puanı sınıf mevcudu değişkenine göre incelenmiştir. Ulaş1lan bulgular Tablo 6'da sunulmuştur:

Tablo 6. Yazılı Anlatım Becerisinin Sınıf Mevcudu Değişkenine Göre Betimlenmesi

\begin{tabular}{|c|c|c|c|c|c|c|c|c|c|c|}
\hline \multicolumn{5}{|c|}{ Betimsel Analiz Sonuçları } & \multicolumn{6}{|c|}{ ANOVA Sonuçları } \\
\hline $\begin{array}{l}\text { Sinif } \\
\text { Mevcudu }\end{array}$ & $\mathrm{N}$ & $X$ & $\mathrm{~S}$ & $\begin{array}{c}\text { Varyansın } \\
\text { Kaynağ1 }\end{array}$ & $\begin{array}{l}\text { Kareler } \\
\text { Toplamı }\end{array}$ & $\mathrm{Sd}$ & $\begin{array}{c}\text { Kareler } \\
\text { Ortalamas1 }\end{array}$ & $\mathrm{F}$ & $\mathrm{p}$ & Fark \\
\hline 10-15 kişi & 151 & 52,94 & 12,239 & G. Aras1 & 1249,923 & 3 & 416,641 & & & \\
\hline 16-20 kişi & 146 & 53,57 & 10,787 & G. İçi & 65366,151 & 559 & 116,934 & & & \\
\hline $21-25$ kişi & 100 & 57,19 & 9,459 & Toplam & 66616,075 & 562 & & 3,563 &, $014 *$ & $\begin{array}{l}1-3 \\
2-3\end{array}$ \\
\hline 26-30 kişi & 166 & 55,00 & 10,201 & & & & & & & \\
\hline Toplam & 563 & 54,47 & 10,888 & & & & & & & \\
\hline
\end{tabular}

Tablo 6'daki bulgulara göre öğrencilerin yazılı anlatım becerileri sınıf mevcuduna göre anlamlı farklılık göstermektedir $\left(\mathrm{F}_{(3,562)}=3,563 ; \mathrm{p}<, 05\right)$. Bu farklılığın farklılığın hangi gruplar arasında 
olduğunu belirlemek için için Games-Howell testi yapılmıştır. Varyansların eşit olmadığ1 bilinen durumlarda Games-Howell testi daha doğru sonuçlar vermektedir (Field, 2009). 21-25 öğrencisi bulunan sinıflara devam eden öğrenciler ile mevcudu 10-15 ve 16-20 öğrenci olan sınıflara devam eden öğrenciler arasında anlamlı farklılık olduğu anlaşılmıştır.

\section{2. İlkokul Dördüncü Sınıf Öğrencilerinin Yazma Öz Yeterlik İnançlarına İlişkin Bulgular}

Araştırmaya katılan ilkokul dördüncü sınıf öğrencilerinin yazma öz yeterlik inançları incelenmiştir. Elde edilen bulgular Tablo 7'de sunulmuştur:

Tablo 7. Yazma Öz Yeterlik İnancının Betimlenmesi

\begin{tabular}{lccc}
\hline & $\mathrm{N}$ & $\overline{\mathrm{X}}$ & $\mathrm{S}$ \\
\hline Yazma Öz Yeterlik & 563 & 26,35 & 2,83 \\
\hline
\end{tabular}

Tablo 7'ye göre öğrencilerin yazma öz yeterlik inançları $(\bar{X}=26,35 ; s=2,83)$ yüksek düzeydedir. $\mathrm{Bu}$ bulgu, ögrencilerin yazma konusunda kendilerini yetkin hissettiklerinin bir göstergesidir.

İlkokul dördüncü sınıf öğrencilerinin yazma öz yeterlik düzeyleri cinsiyet değişkenine göre incelenmiş ve bağımsız örneklemler $\mathrm{t}$ testi yapılmıştır. Elde edilen bulgular Tablo 8'de sunulmuştur:

Tablo 8. Yazma Öz Yeterlik İnancının Cinsiyete Göre İncelenmesi

\begin{tabular}{lcccccc}
\hline \multicolumn{1}{c}{ Cinsiyet } & $\mathbf{N}$ & $\overline{\mathbf{X}}$ & $\mathbf{S}$ & Sd & t & p \\
\hline Kiz & 318 & 26,65 & 2,73 & \multirow{2}{*}{561} & \multirow{2}{*}{2,89} & \multirow{2}{*}{$0,04 *$} \\
\hline Erkek & 245 & 25,96 & 2,92 & & \\
\hline
\end{tabular}

*p<,05

Tablo 8'e göre yazma öz yeterlik düzeyinin kız öğrenciler lehine anlamlı farklılık gösterdiği $\left(\mathrm{t}_{(561)}=2,89,<, 05\right)$ anlaşılmaktadır. Buna göre kız öğrencilerin yazma öz yeterlik inançları erkek öğrencilerle kıyaslandığında daha yüksektir.

İlkokul dördüncü sınıf öğrencilerinin yazma öz yeterlik düzeylerinin sınıf mevcutlarına göre farklılık gösterip göstermediğini belirlemek amacıyla tek yönlü varyans analizi yapılmış ve bulgular Tablo 9'da sunulmuştur:

Tablo 9. Yazma Öz Yeterlik İnancının Sınıf Mevcuduna Göre Betimlenmesi

\begin{tabular}{|c|c|c|c|c|c|c|c|c|c|c|}
\hline \multicolumn{5}{|c|}{ Betimsel Analiz Sonuçları } & \multicolumn{6}{|c|}{ ANOVA Sonuçları } \\
\hline $\begin{array}{l}\text { Sinıf } \\
\text { Mevcudu }\end{array}$ & $\mathrm{N}$ & $X$ & $\mathrm{~S}$ & $\begin{array}{c}\text { Varyansın } \\
\text { Kaynağ } 1\end{array}$ & $\begin{array}{c}\text { Kareler } \\
\text { Toplam1 }\end{array}$ & $\mathrm{Sd}$ & $\begin{array}{c}\text { Kareler } \\
\text { Ortalamas }\end{array}$ & $\mathrm{F}$ & $\mathrm{p}$ & Fark \\
\hline 10-15 kişi & 151 & 26,90 & 2,541 & G. Aras1 & 80,606 & 3 & 26,869 & & & \\
\hline 16-20 kişi & 146 & 26,35 & 2,916 & G. İçi & 4434,055 & 559 & 7,932 & & & \\
\hline $21-25$ kişi & 100 & 26,28 & 2,659 & Toplam & 4514,661 & 562 & & 3,387 &, $018^{*}$ & $1-4$ \\
\hline 26-30 kişi & 166 & 25,90 & 3,048 & & & & & & & \\
\hline Toplam & 563 & 26,36 & 2,834 & & & & & & & \\
\hline
\end{tabular}

Tablo 9'daki bulgulara göre araştırmaya katılan öğrencilerin yazma öz yeterlik inançları sınıf mevcudu değişkenine göre anlamlı farklılık göstermektedir $\left(\mathrm{F}_{(3,562)}=3,387 ; \mathrm{p}<, 05\right)$. Farklılığın hangi gruplar arasında olduğunu anlamak için Dunnet $C$ testi yapılmış, anlamlı farklılı̆̆ın 10-15 öğrencisi olan sınıflardaki öğrenciler ile 26-30 öğrencisi olan sınıflardaki öğrenciler arasında 
İlkokul Öğrencilerinin Yazılı Anlatım Becerileri ile Yazma Öz Yeterlik İnançlarının İncelenmesi

farklılık göterdiği anlaşılmıştır. Bu bulgudan hareketle mevcudu kalabalık olmayan sınıflardaki öğrencilerin yazma öz yeterlik inançlarının kalabalık sınıflardaki öğrencilere göre daha güçlü olduğu şeklinde yorumlanabilir.

\section{3. İlkokul Dördüncü Sınıf Öğrencilerinin Yazılı Anlatım Becerileri İle Yazma Öz Yeterlik İnançları Arasındaki İlişkinin İncelenmesi}

İlkokul dördüncü sınıf öğrencilerinin yazılı anlatım beceri düzeyleri ile yazma öz yeterlik inançları arasında bir ilişki olup olmadığı belirlemek amacıyla Pearson Korelasyon katsayısı hesaplanmıştır. Elde edilen bulgular Tablo 10'da sunulmuştur:

Tablo 10. Yazma Öz Yeterlik İnancı ile Yazılı Anlatım Becerisi Arasındaki İlişkinin Betimlenmesi

\begin{tabular}{lcc}
\hline & Yazma Öz Yeterliği & Yazllı Anlatım Becerisi \\
\hline Yazma Öz Yeterliği & 1 &, $161^{* *}$ \\
Yazılı Anlatım Becerisi & & 1 \\
\hline$* * p<, 01$ & &
\end{tabular}

Tablo 10'daki bulgular öğrencilerin yazma öz yeterlik inanç düzeyleri ile yazılı anlatım becerileri arasında pozitif yönlü, zayıf ve anlamlı bir ilişki olduğunu göstermektedir $(\mathrm{p}<, 01 ; \mathrm{r}=$ .161). İlişki düzeyinin pozitif ve anlamlı olması bu iki değişkenden birinin düzeyindeki artışın düşük düzeyde de olsa diğer değişkenin düzeyinin de artmasını sağladığı ifade edilebilir.

\section{Tartışma ve Sonuçlar}

Araştırmada ilkokul dördüncü sınıf öğrencilerinin yazma öz yeterlik inançları ile yazılı anlatım becerileri arasındaki ilişki incelenmiştir. Araştırma sonuçları araştırmanın örneklemini oluşturan ilkokul dördüncü sınıf öğrencilerinin yazılı anlatımda başarılı olduğunu göstermektedir. Ancak puan ortalamaları yüksek düzeyde olsa da orta puan aralığının sınırında olduğu fark edilmiştir. Yazılı anlatımda üretilen metinlerin içerik özelliklerinin (giriş, gelişme, konu, ana fikir, tutarlık vb.) biçim ve anlatım özelliklerine göre daha iyi bir düzeyde olduğu anlaşılmıştır. Elma ve Bütün (2015) tarafindan yapılan araştırmaya göre öğretmenler ilkokul ve ortaokul öğrencileri için yazılı anlatımda içerik ve biçim özelliklerinin çok zorlanılan bir alan olduğunu; özellikle bilgilendirici metin yazamadıklarını, bağımsız yazma becerisine sahip olmadıklarını belirtmişlerdir. Katrancı ve Temel'in (2019) araştırmalarında ilkokul dördüncü sınıf öğrencilerinin öyküleyici türde metin yazma becerilerinin orta, bilgilendirici türde metin yazma becerilerinin ise düşük düzeyde olduğu tespit edilmiştir. Farklı araştırmaların sonuçları kıyaslandığında ilkokul öğrencilerinin yazılarında uygun biçimsel özelliklere yer vermede yetersiz kaldıkları anlaşılmaktadır.

Araştırma konusu cinsiyet değişkeni bakımından da ele alınmıştır. Buna göre ilkokul dördüncü sınıf öğrencilerinin yönergelerdeki konuları içeren yazılarının biçim, dil, anlatım ve içerik özellikleri ile toplam yazılı anlatım puanları incelenerek sonuçlar değerlendirildiğinde kız öğrencilerin erkek öğrencilere göre daha başarılı olduğu belirlenmiştir. Yapılan araştırma, alan yazındaki başka araştırmaların sonuçlarıyla benzerlik göstermektedir. Ögüt (2018) ilkokul dördüncü sınıf öğrencilerinin yazı okunaklılığını incelediği araştırmada, kız öğrencilerin yazılarının erkek öğrencilere göre daha okunaklı ve bu özellikten alınan puanların da daha yüksek olduğu sonucuna ulaşmıştır. Araştırmaya katılan öğrenciler tarafından yazılan metinlerin içerik özelliklerinin sınıf mevcudu değişkenine göre bir farklılık göstermediği sonucu ortaya çıkmıştır. Ancak toplam yazılı anlatım puanları ile yazıların biçim ve anlatım özellikleri, mevcudu kalabalık olan sinıflarda daha yüksektir. Bunun sebebi olarak mevcudu kalabalık olan 
sınıfların etkileşimde bulunduğu öğrenci sayısının fazlalığı gösterilebilir. Bu etkileşimin de öğrencilerin yazılı anlatım becerilerini olumlu yönde etkilediği şeklinde değerlendirme yapılabilir.

Araştırmanın sonuçlarına göre ilkokul dördüncü sınıf öğrencisinin yazma öz yeterlik inançları yüksektir. Yazı yazması beklenen veya yazı yazmayı öğrenmesi gereken kimselerin kendi yazma becerileri ile ilgili olumlu bir inanca sahip olması metin oluşturma sürecinin verimli geçmesine hizmet edebilir. Bu bakımdan, araştırmaya katılan ilkokul öğrencilerinin yazılı anlatım puanlarının genel olarak yüksek ve orta düzeyde olmasının bu sonuç ile ile uyumlu olduğu düşünülebilir. Benzer sonuçlara başka araştırmalarda da rastlanmıştır. Akar ve Özber'in (2018) yaptığı araştırmada ilkokul öğrencilerinin yazma öz yeterlik inanç düzeylerinin iyi olduğu sonucuna ulaşılmıştır. Örneğin, Manay, Türkel ve Savaş (2017); Kuşdemir ve Gülcegül (2018); Özonat (2015); Yılmaz, Yiğit ve Kaşarcı (2012) tarafından yapılan araştırmalarda ilkokul ve ortaokul öğrencilerinin yazma öz yeterlik inançlarının yüksek ve yeterli düzeyde olduğu belirlenmiştir. Kişilerin kendilerine ait öz yeterlik inançlarının güçlü ve anlamlı olması, onların başarılarını daha da artırmaktadır (Demir, 2013).

Araştırmaya katılan kız öğrencilerin yazma öz yeterlik inancının erkeklere göre daha yüksek olduğu belirlenmiştir ki bu sonuçlarla uyumlu olabilecek farklı araştırmaların sonuçları da mevcuttur. Örneğin Akar ve Özber (2018); Kuşdemir ve Gülcegül (2018); Özonat (2015); Baş ve Şahin (2012); Yıldız ve Ceyhan (2016); Aşılıoğlu ve Özkan (2013) tarafından yapılan çalışmalarda yazma öz yeterliğinin, kızların lehine anlamlı olduğu belirlenmiştir. Kurbanoğlu (2004) bu durumu eğitim düzeyi, yaş ve cinsiyet özelliklerinin bireyde "ben de başarabilirim/yapabilirim duygusu" yarattığını, başarısızlığın ise bireyin kendi başarma kapasitesi konusunda kuşkulanmasına sebep olabileceği şeklinde açıklamaktadır. Yazma, kendi içinde okuma, düşünme ve düzgün ifade etme becerilerini içermesi ve uygulaması zor bir eylem olduğundan öğrencilerin bu etkinlikten uzak durduğu bilinmektedir (Ungan, 2007). Bu tutum, yazma becerisinin gelişmesini de yavaşlatmaktadır. Yazma öğretiminin gelişim sürecini etkileyen; öğretim sürecinden, öğrenciden ve öğretmenden kaynaklanan sorunlar da vardır. Araştırmaya katılan ilkokul dördüncü sınıf öğrencilerinin yazma öz yeterlikleri, mevcudu az olan sınıflarda daha yüksektir. Bunun sebebi olarak, az sayıda öğrencinin olduğu sınıflarda ögrencilerin yazmadan önce veya yazarken kendilerini daha rahat hissetmeleri ve bunun yazma eğilimini geliştirmesi gösterilebilir.

Araştırmanın sonuçlarına göre yazma öz yeterlik inancı ile yazılı anlatım becerisi arasında düşük ve olumlu yönlü anlamlı bir ilişki olduğu anlaşılmıştır. Demir (2013), ilköğretim sekizinci sınıf öğrencilerinin yazılı anlatım puanları ile yazma öz yeterlik algıları arasındaki ilişkilerini incelemiş, olumlu yönde, düşük düzeyde ve anlamlı bir ilişki tespit etmiştir. Shell, Murphy ve Bruning (1989) tarafindan yapılan araştırmada üniversite öğrencilerinin yazma öz yeterlik algıları ve 20 dakikada yazılı bir metni oluşturma başarıları arasında olumlu yönde anlamlı bir ilişki olduğu belirlenmiştir. Pajares (2003) öz yeterlik inancı ve motivasyon faktörlerinin etkisi hakkında yapılan çalışmaları değerlendirmiş̧tir. Araştırma sonucunda yazma öz yeterlik inancının, motivasyon bileşenleri ile yazma becerisi başarısı arasında ilişki bulunduğunu göstermiştir. Farklı araştırma sonuçları ile bu araştırmanın sonuçları örtüşmektedir. Bireylerin yazmaya yönelik öz yeterlik algısının ve yapabileceğine olan inancının yazma başarısı ile ilişkili olduğu vurgulanabilir.

Araştırmanın sonuçlarına bağlı olarak öğretmenlere ve araştırmacılara bazı önerilerde bulunulabilir: 
1. Öğrencilerin yazılı anlatımlarının geliştirilmesi için yazılan metinlerin öğretmenler tarafından denetlenmesi, yapılan hataların belirlenmesi ve bunların düzeltilmesi için rehberlik edilmesi önerilebilir.

2. İlkokul öğrencilerinin yazdığı metinlerde metnin tutarlılığ 1 , giriş, gelime, sonuç bölümlerinin oluşturulması, fikirlerin anlamlı sıralanması, ana fikrin yerleştirilmesi gibi metnin içeriğini oluşturan özelliklerle ilgili eylem araştırmaları ve deneysel araştırmalar artırılabilir.

3. Yeni boylamsal araştırmalar tasarlanarak ilkokul öğrencilerinin yazma öz yeterlik inançlarının ve yazılı anlatım becerilerinin belirli bir zaman dilimi içerisindeki gelişimi ve değişimi incelenebilir.

\section{Kaynaklar}

Akar, C., \& Özber, M. (2018). İlkokul dördüncü sınıf öğrencilerinin yazma öz yeterliklerinin çeşitli değişkenler açısından incelenmesi. Avrasya Dil Eğitimi ve Araştırmaları Dergisi, 2(1), 75-89.

Akyol, H. (2015). Türkçe ilk okuma yazma öğretimi. Ankara: Pegem Akademi Yayıncılık.

Akyol, H. (2006). Yeni programa uygun Türkçe öğretim yöntemleri. Ankara: Kök Yayıncılık.

Altunkaya, H. (2019). Yazma eğitimi. H. Kavruk-H. Kurnaz (Ed.) Türkçe Öğretimi. Ankara: Nobel Yayınevi.

Aşılıoğlu, B., \& Özkan, E. (2013). Ortaokul öğrencilerinin yazma kaygılarının bazı değişkenler açısından incelenmesi: Diyarbakır örneği. The Journal Of Academic Social Science Studies, 6(6), 83-111.

Bandura, A. (1997). Self-efficacy: The exercise of control. New York: Freeman.

Bandura, A. (1989). Human agency in social cognitive theory. American Psychological Association, 44(9), 1175-1184.

Baş, G., \& Şahin, C. (2012). İlköğretim öğrencilerinin okuma tutumları, yazma eğilimleri ile Türkçe dersindeki akademik başarıları arasındaki ilişki. Turkish Studies, 7(3), 555-572.

Batur, Z., Erkek, G., Özen, N. E., \& Ellialtı, M.(2017). Yazılı anlatım yanlışlarının/hatalarının öğrenim düzeylerine göre incelenmesi. International Journal of Language Academy, 5(4), 61-73.

Cohen, L., Manion, L., \& Morrison, K.(2007). Research methods in education (6. bask1). New York: Routledge.

Demir, T. (2013). İlköğretim öğrencilerinin yaratıcı yazma becerileri ile yazma özyeterlik algıs1 ilişkisi üzerine bir çalışma. Uluslararası Türkçe Edebiyat Kültür Eğitim Dergisi, 2(1), 84114.

Elma, C., \& Bütün, E. (2015). İlkokul ve ortaokul öğrencilerinin yazılı anlatım becerilerine ilişkin öğretmen görüşleri. Abant İzzet Baysal Üniversitesi Eğitim Fakültesi Dergisi, 15(2), 104-131.

Field, A. (2009). Discovering statistics using SPSS. USA: Sage Publications

Göçer, A. (2010). Türkçe öğretiminde yazma eğitimi. Uluslararası Sosyal Araştırmalar Dergisi, 3(12), 178-195.

Gök, B., \& Baş, Ö. (2020). İlkokul 1. sınıf öğrencilerinin dik temel yazılarının okunaklılığı üzerine bir inceleme. Ana Dili Eğitimi Dergisi, 8(2), 572-585. 
Gündüz, O., \& Şimşek, T. (2011). Uygulamall yazma eğitimi. Ankara: Grafiker Yayınları.

Güneş, F. (2013). Türkçe ögrretimi yaklaşım ve modeller. Ankara: Pegem Akademi Yayıncılık.

Güneş, F., Kuşdemir, Y., \& Bulut, P. (2017). Yazma öz yeterlik ölçeğinin psikometrik özellikleri. The Journal of Academic Social Science Studies, 58, 101-114.

Kaptan, S. (1998). Bilimsel araştırma ve istatistik teknikleri (11. baskı). Ankara: Tekışık Yayınları.

Karadağ, Ö., \& Maden, S. (2013). Yazma eğitimi: Kuram, uygulama, ölçme ve değerlendirme. İçinde A. Güzel \& H. Karatay (Ed.), Türkçe öğretimi (s. 263-302). Ankara: Pegem Akademi.

Karadağ, R., \& Kayabaşı, B. (2011). Yazılı anlatım becerilerinin geliştirilmesinde okuma metinleri olarak gazete köşe yazılarının kullanılması. Turkish Studies Journal, 6(3), 9891010 .

Katranc1, M., \& Temel, S. (2019). İlkokul öğrencilerinin yazılı anlatım becerileri, yazmaya yönelik tutumları ve yazma kaygıları arasındaki ilişki. AVRASYA Uluslararası Araştırmalar Dergisi, 7(17), 322-356.

Katranc1, M., \& Kuşdemir, Y. (2016). Okumada kayg1 ve anlama: Ana fikri bulamıyorum öğretmenim!. Ĕgitim ve Bilim, 41(183), 251-266.

Keçik, İ., \& Uzun, L. (2004). Türkçe sözlü ve yazılı anlatım. Eskişehir: Anadolu Üniversitesi Yayınları.

Kellog, R. T. (2008). Training writing skills: A cognitive developmental perspective. Journal Of Writing Research, 1(1), 1-26.

Kodan, H. (2016). Yazma güçlüğü olan üçüncü sınıf öğrencisinin el yazısı okunaklılığının geliştirilmesi: Eylem araştırması. Türkiye Sosyal Araştırmalar Dergisi, 2, 523-539.

Köklük, N., Büyüköztürk, Ş., \& Çokluk, Ö. (2007). Sosyal bilimler için istatistik (İkinci baskı). Ankara: Pegem Akademik Yayınları.

Kurbanoğlu, S. S. (2004). Öz-yeterlik inancı ve bilgi profesyonelleri için önemi. Bilgi Dünyası, $5(2), 137-152$.

Kuşdemir, Y. (2018). İlkokul çağı çocuklarında dil gelişimi. İçinde F. Güneş \& S. Sidekli (Ed.).Illkokulda Türkçe öğretimi (s. 17-58). Ankara: Eğiten Kitap Yayıncılık.

Kuşdemir, Y., \& Gülcegül, S. (2018). İlkokul dördüncü sınıf öğrencilerinin yazma öz yeterlik inançları: Yazabilirim! Uluslararası Sosyal Araştırmalar Dergisi, 11(59), 779-785.

Manay, E. B., Türkel, A., \& Savaş, B. (2017). Kelime ağı yönteminin ilköğretim 6. sınıf öğrencilerinin yazmaya yönelik tutumlarına ve yazma öz yeterlik algısına etkisi. Electronic Turkish Studies, 12(14), 257-284.

Mascle, D. D. (2013). Writing self-efficacy and written communication skills. Teaching Students to Write for the Workplace Part 2, 76(2), 216-225.

Öğüt, A. (2018). İlkokul ögrencilerinin yazım hatalarının ve yazılarının okunaklılık düzeylerinin incelenmesi (Yayımlanmamış yüksek lisans tezi) Gaziantep Üniversitesi, Eğitim Bilimleri Enstitüsü, Gaziantep.

Özdemir, C., \& Erdoğan, T. (2017). Sınıf öğretmeni adaylarının ilkokuma ve yazma öğretimine ilişkin öz yeterlik inançlarının belirlenmesi. Abant İzzet Baysal Üniversitesi Eğitim Fakültesi Dergisi, 17(1), 314-331. 
İlkokul Öğrencilerinin Yazılı Anlatım Becerileri ile Yazma Öz Yeterlik İnançlarının İncelenmesi

Özonat, Z. (2015). Sekizinci sınıf öğrencilerinin yazma öz yeterlik algıları. Erzincan Üniversitesi Sosyal Bilimler Enstitüsü Dergisi, 9(2), 207-220.

Pajares, F. (2007). Empirical properties of a scaie to assess writing self-efficacy in school contexts. Measurement and Evaluation in Counseling and Development, 39, 239-249.

Pajares, F. (2003). Self-efficacy beliefs, motivation, and achievement in writing: A review of the literatüre. Reading \& Writing Quarterly: Overcoming Learning Difficulties, 19, 139158.

Pajares, F., \& Valiante, G. (1997). Influence of self-efficacy on elementary students' writing. The Journal of Educational Research, 90, 353-360.

Sharpio, E. S. (1996). Academic skills problems: Direct assessments and intervention (2. bask1). New York: Guilford Press.

Sharples, M. (1999). How we write (1. bask1). Canada: Routledge.

Shell, F. D., Murphy, C. C., \& Bruning, H. R. (1989). Self-efficacy and outcome expectancymechanisms in reading and writing achievement. Journal of Educational Psychology, 81, 91-100.

Soylu, M., \& Akkoyunlu, B. (2019). Yazma öz yeterlik ölçeğinin Türkçeye uyarlanması. Kastamonu Ĕ̈itim Dergisi, 27(5), 2233-2242.

Stang, K. K. (2001). Writing self-efficacy, story-writing, and teacher ratings of sixth grade middle school language arts students (Yayımlanmamış doktora tezi), Northwestern University, Evanston.

Tabachnick, B. G., \& Fidell, L. S. (2013). Using multivariate statistics (6. bask1). USA: Pearson Education Limited.

Türk Dil Kurumu (2019). Güncel Türkçe Sözlük. https://sozluk.gov.tr/

Ungan, S. (2007). Yazma becerisinin geliştirilmesi ve önemi. Erciyes Üniversitesi Sosyal Bilimler Enstitüsü Dergisi, 1(23), 461-472.

Uzunsakal, E., \& Yıldız, D. (2018). Alan araştırmalarında güvenilirlik testlerinin karşılaştırılması ve tarımsal veriler üzerine bir uygulama. Uygulamalı Sosyal Bilimler Dergisi, 2(1), 14-28.

Yıldız, M., \& Ceyhan, S. (2016). İlkokul 4.sınıf öğrencilerinin okuma ve yazma kaygılarının çeşitli değişkenler açısından incelenmesi. Turkish Studies, 11(2), 1301-1316

Yılmaz, E., Yiğit, R., \& Kaşarc1, İ. (2012). İlköğretim öğrencilerinin özyeterlilik düzeylerinin akademik başarı ve bazı değişkinler açısından incelenmesi. Mehmet Akif Ersoy Üniversitesi Ĕ̈itim Fakültesi Dergisi, 1(23), 371-388.

\section{EXTENDED ABSTRACT}

\section{Introduction}

Writing is a means to discover ideas and to produce new knowledge. Requiring the individual to possess knowledge of proper grammar, spelling, punctuation, and style, this skill necessitates one to engage in diverse mental and emotional exercises in addition to writing on a regular basis. Accordingly, writing is a language skill through which the emotions, thoughts, experiences, knowledge, observations, and dreams constructed and expressed in the writer's mind are communicated using symbols and signs through the coordination of his/her hands, eyes, and brain. A written text has two fundamental characteristics-legibility and content. 
Legibility is obtained by forming letters correctly and ordering them on a straight line with appropriate and proportionate spacing between letters and words. Legible writing allows one to articulate his/her emotions and thoughts in a coherent manner. Developed during the mental stage of the writing process, content consists of a topic, plan, titles, sentence and paragraph structure, vocabulary, and the main idea. Prior to writing, a topic is decided upon and a plan is created. Content, moreover, pertains to how the topic will be expressed, how the writer's emotions and ideas are articulated, and how s/he will construct a pattern of meaning. Having high writing self-efficacy beliefs indicates that one considers him/herself to have effective writing skills and knowledge.

\section{Purpose}

The purpose of this study is to examine whether there is a correlation between primary fourthgrade students' writing self-efficacy beliefs and their written expressions skills. To this end, answers to the following questions were sought:

1. How well-developed are primary fourth-grade students' written expression skills?

2. Do primary fourth-grade students' written expression skills:

2.1. differ significantly by gender?

2.2. differ significant by classroom size?

3. How do primary fourth-grade students rate their own writing proficiency levels?

4. Do primary fourth-grade students writing self-efficacy beliefs:

4.1. differ significantly by gender?

4.2. differ significantly by classroom size?

5. Is there a meaningful correlation primary fourth-grade students' written expression skills and their writing self-efficacy beliefs?

\section{Method}

We employed a correlational survey model to identify the correlation between two variables (i.e., writing self-efficacy belief and written expression skills). Selected from the 2,594-student universe using simple random sampling, a total of 563 students were included in the study's sample. The study was conducted in Kirikkale, Turkey in 2019. The data collection tools employed were (1) a Personal Information Form, (2) a List of Instructions for Written Expression, (3) a Written Expression Assessment Form, and (4) the Writing Self-Efficacy Scale. Permission has been obtained from the national education directorate for data collection. We finalized the program's schedule after meeting with school administrators and teachers. Data were collected during two different sessions. During the first session, students completed the Personal Information Form and Writing Self-Efficacy Scale whereas data on their written expression were collected during the second. It took three months to collect all data, which were then analyzed using a computer-based statistics package. Arithmetic means and standard deviations were calculated to gauge students' written expression skills and self-efficacy belief levels. A correlation analysis was further conducted to determine whether there was a relationship between students' writing self-efficacy levels and their written expression skills.

\section{Findings}

Although the students participating in the study obtained high written expression scores, upon deeper scrutiny, these scores were found to be close to the upper boundary of the intermediate cut-off point. Students' compositions contained intermediate-level style, language, and expression and high-level content, though it was still close to the threshold between the two divisions. As a result, the fourth-grade students in this study exhibit well-developed written 
expression skills. Moreover, the female students' written expression scores and those of the style, language, expression and content of their compositions were found to be higher than their male counterparts, and this difference was statistically significant. Although classroom size produced no meaningful difference in students' content-related dimensions, a statistically significant difference in the style, language, and expression scores of students in classrooms of 21-25 compared to classrooms of 10-15 and of 16-20 students in favor of students in classrooms containing 21-25 students. Students were found to have high writing self-efficacy beliefs, indicating that they considered themselves to be proficient in writing. A statistically significant difference in writing self-efficacy beliefs by gender in favor of females was moreover identified. With regard to classroom size, a statistically significant difference was found between the writing self-efficacy scores of students in classrooms containing 10-15 and 26-30 students in favor of students in the former group. Based on this finding, it may be concluded that students in smaller classrooms have stronger writing self-efficacy beliefs compared to those in larger classrooms. A low, positive, statistically significant relationship was found between the students' writing self-efficacy beliefs and their written expression skills. The fact that this correlation is both positive and statistically significant means that an increase in one of these two variables precipitates an increase, even if small, in the other.

\section{Discussion}

The fourth-grade students in this study were found to be generally proficient in their written expression abilities. However, although students did obtain high scores in this area, they were near the upper boundary of the intermediate cut-off point. Students were found to be more proficient in content-related dimensions (e.g., introduction, development, subject, main idea, intratextual consistency) than in style and expression. Similar findings were found in other national studies. After analyzing students' total written expression scores and subscales by gender, female students were found to be more proficient in style, language, expression, and content-related dimensions included in the writing instructions list compared to their male counterparts. In short, the findings indicate that the writing self-efficacy scores of the 563 primary fourth-grade students were universally high. An individual's having strong self-efficacy beliefs may help to increase their writing performance. It is therefore believed that primary school students consider themselves to have well-developed writing skills. This study further found there to be a low, positive, statistically significant relationship between students' writing self-efficacy beliefs and their written expression skills. Studies focusing on various grade levels in both primary and middle school have found there to be a statistically significant, albeit low correlation between writing self-efficacy beliefs and writing performance. Such results indicate the likelihood that one's self-efficacy beliefs toward writing have an effect on that individual's writing performance.

\section{Recommendations}

Text The following recommendations can be made based on the study's findings:

- Teachers should read students' compositions, indicate their mistakes, and guide them in how to correct their mistakes, as to this will help students improve their abilities to express themselves in writing.

- The number of action or experimental studies focusing on content-related topics like intratextual consistency, how to construct the introduction, development, and conclusion sections of a text, how to order ideas, and how to incorporate the main idea in primary school students' compositions can be increased. 
- Further longitudinal studies can be designed to examine the development and changes in primary students' writing self-efficacy beliefs and written expression skills over a specific time period.

\section{Etik Kurul İzin:}

$\mathrm{Bu}$ makale, "İlkokul Öğrencilerinin Yazılı Anlatım Becerileri ile Yazma Öz Yeterlik İnançlarının İncelenmesi” adlı yüksek lisans tezinden üretilmiştir. Araştırmanın verilerinin toplanabilmesi için öncelikle Milli Eğitim Bakanlığı'nın Araştırma, Yarışma ve Sosyal Etkinlik birimine (https://ayse.meb.gov.tr/basvurudev/\#) çevrim içi yapılan başvuru sonucu izin belgesi alınıştır. Bu izin belgesi, araştırmanın amacı ve veri toplama araçlarını içeren ekler dosyası Kırıkkale Üniversitesi Sosyal Bilimler Enstitüsü aracıllı̆ı ile Kırıkkale İl Milli Eğitim Müdürlügü̈'ne iletilmiştir. Kırıkkale İl Milli Eğitim Müdürlüğü'nün 25.04.2019 tarihli ve 79140815-44-E.8265962 sayılı izin belgesi ile araştırmanın verileri toplanmıştır. Veri toplama uygulaması 2019 yılında Mayıs ayı sonunda tamamlanmıştır. "İlkokul Öğrencilerinin Yazılı Anlatım Becerileri ile Yazma Öz Yeterlik İnançlarının İncelenmesi” adlı yüksek lisans tezi 22.07.2020 tarihinde Kırıkkale Üniversitesi Sosyal Bilimler Enstitüsü tarafindan kabul edilmiştir. "İlkokul Öğrencilerinin Yazılı Anlatım Becerileri ile Yazma Öz Yeterlik İnançlarının İncelenmesi” başlıklı araştırmada etik kurallara uyulmuştur. 